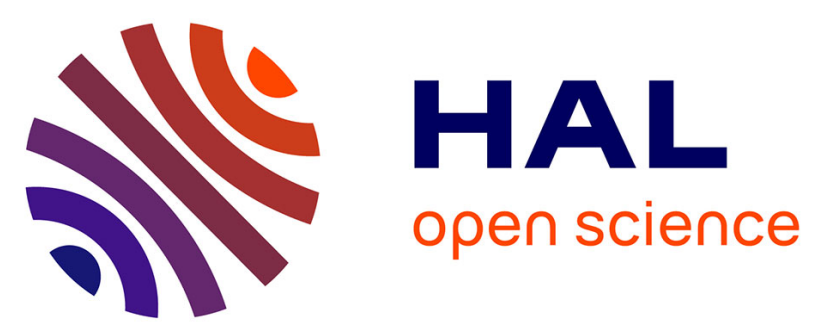

\title{
Validity of the centrifuge method for determining the water retention properties of tropical soils
}

\author{
Adriana Reatto-Braga, Euzebio Medrado da Silva, Ary Bruand, Éder de \\ Souza Martins, Jorge Enoch Furquim Werneck Lima
}

\section{To cite this version:}

Adriana Reatto-Braga, Euzebio Medrado da Silva, Ary Bruand, Éder de Souza Martins, Jorge Enoch Furquim Werneck Lima. Validity of the centrifuge method for determining the water retention properties of tropical soils. Soil Science Society of America Journal, 2008, 72 (6), pp.1547-1553. 10.2136/sssaj2007.0355N . insu-00311740

\section{HAL Id: insu-00311740 \\ https://hal-insu.archives-ouvertes.fr/insu-00311740}

Submitted on 31 Oct 2008

HAL is a multi-disciplinary open access archive for the deposit and dissemination of scientific research documents, whether they are published or not. The documents may come from teaching and research institutions in France or abroad, or from public or private research centers.
L'archive ouverte pluridisciplinaire HAL, est destinée au dépôt et à la diffusion de documents scientifiques de niveau recherche, publiés ou non, émanant des établissements d'enseignement et de recherche français ou étrangers, des laboratoires publics ou privés. 
Validity of the centrifuge method for determining the water retention properties of tropical soils

Adriana Reatto ${ }^{\mathrm{a}, \mathrm{b}}$, Euzebio Medrado da Silva ${ }^{\mathrm{a}}$, Ary Bruand ${ }^{\mathrm{b}, *}$, Eder Souza Martins $^{\mathrm{a}}$, Jorge Enoch Furquim Werneck Lima ${ }^{a}$

${ }^{a}$ Empresa Brasileira de Pesquisa Agropecuária (Embrapa Cerrados), BR 020, km 18, 73310-970, Planaltina, Distrito Federal, Brazil,

${ }^{\text {b} U n i v e r s i t e ́ ~ d ' O r l e ́ a n s, ~ C N R S / I N S U, ~ U n i v e r s i t e ́ ~ d e ~ T o u r s, ~ I n s t i t u t ~ d e s ~ S c i e n c e s ~ d e ~ l a ~}$ Terre d'Orléans (ISTO) UMR6113, 1A rue de la Férollerie 45071 Orléans,

France Cedex 2,

*Corresponding author: tel.: 33-2-38417024; fax: 33-2-38417308. Email address: Ary.Bruand@univ-orleans.fr (A. Bruand)

\begin{abstract}
This study compared the centrifuge and pressure plate methods with appropriate run durations. Samples collected in tropical soils located in Brazil along a 10-km local hydrosequence across the Cerrado-Amazonia transition (Set 1) and along a 350-km regional toposequence across the Cerrado region (Set 2) were selected to compare and discuss statistically the similarity of the soil water retention recorded by using the pressure plate and centrifuge methods. The results showed good agreement $\left(R^{2}=0.99\right)$ for the 1:1 comparison of measured pointwise soil water content values (Set 1) as well as for the fitted soil water content curves by the van Genuchten model using data points obtained with the two methods (Set 2). Thus, the centrifuge method should be considered as an appropriate method for determining soil water retention properties not only because of similar results with the pressure plate method but also because it is much less time consuming.
\end{abstract}




\section{INTRODUCTION}

The relationship between soil-water content and its corresponding water potential is one of the basic parameters required to model water movement. Among the earliest works dealing with that relationship, Briggs and McLane (1910) defined the equivalent moisture as being the soil-water content recorded when a 1-cm long soil sample is centrifuged for $40 \mathrm{~min}$ in a gravitational field equal to $10^{3}$ times the acceleration of gravity. Thus, they were the first to use a variation of the gravitational field by centrifugation to apply a particular value of water potential to a soil sample. The method was questioned later by Thomas and Harris (1925) who showed that the equivalent moisture was influenced by the amount of material centrifuged and the physical and chemical conditions of the centrifugation. Russel and Richards (1938) extended the method by presenting a rather complete mathematical treatment of the centrifuge theory for calculating the water potential corresponding to a measured water content of centrifuged soil samples.

After the development of the pressure plate apparatus (Richards and Fireman, 1943), the centrifuge technique was noticeably set aside, probably due to difficulties in having centrifuges with capability to develop speed of rotation sufficiently high to obtain soil water water potentials near the corresponding permanent wilting point. Later on, the centrifuge technique came back into consideration with the work done by Odén (1975), who proposed a mathematical formalism to put forth an integral method for the determination of the soil water retention curve by centrifugation. This method was experimentally tested using soil samples varying in composition and comparing the results with those recorded with suction or pressure plates, showing a relatively good agreement between the two methods. 
Nowadays, the centrifuge technique has been also applied to determine the unsaturated hydraulic conductivity (see Nimmo et al., 2002; Singh and Kuriyan, 2002; Caputo and Nimmo, 2005; Simunek and Nimmo, 2005; Nakajima and Stadler, 2006). In addition, the centrifuge has been used in geotechnical engineering to carry out scaled model tests for studies on soil mechanical behavior and contaminant movement in groundwater (Arulanandan et al., 1988; Taylor, 1995).

Such a limited appeal for the centrifuge method for determining the soil water retention is frequently related to the fact that many researchers are uncertain about its accuracy as compared to the results obtained from the pressure plate method. Indeed, even though Freitas Junior and Silva (1984) derived a mathematical equation to calculate the average water potential at a given cross-section of a centrifuged soil sample, thus enabling the determination of different points of the soil-water retention curve from a previously selected rotation speed, they did not perform any statistical analysis to determine the quality of their results. Medeiros (1987) applied the method developed by Freitas Junior and Silva (1984) to an Alfisol and several Oxisols and showed that the water contents obtained with the centrifuge and pressure plate methods were, in general, highly linearly correlated but with appreciable differences at each soil water potential. Centurion et al. (1997) compared the centrifuge method with the pressure plate method applied to representative Brazilian tropical soils. They showed that the results recorded with the centrifuge and pressure plate methods were again highly correlated. Balbino et al. (2002) analyzed data obtained from Brazilian Oxisols and showed that the water content determined at $-10,-33$ and $-1500 \mathrm{kPa}$ were greater when measured with the centrifuge method compared to the pressure plate method. Khanzode et al (2000, 2002), by using a proposed adaptation of a medical centrifuge to measure soil water characteristic curves on artificially packed disturbed soil samples, compared three soils 
with clay contents ranging from 7 to $70 \mathrm{~g} \mathrm{~kg}^{-1}$ and showed also the centrifuge method overestimated the water retention when compared to the data obtained with tempe cells for water potentials varying from -1 to $-600 \mathrm{kPa}$. By testing the run duration, they concluded that 120 minutes of rotation was sufficient to attain equilibrium conditions for the silty soil used but not good enough to reach equilibrium for the heavier soils studied. Meanwhile, Silva and Azevedo (2001, 2002), using soils from the Cerrado Biome, which usually have soil water characteristics typical of sandy soils, showed that the run duration was critical for the precision of the centrifuge method, finding that from 83 to $130 \mathrm{~min}$ were required to reach equilibrium at each applied rotation speed, depending on the soil texture, while the centrifugation time had been 5 to 60 min in the study of Odèn (1975) and 50 to $60 \mathrm{~min}$ in the study of Centurion et al. (1997). A possible explanation for the different water contents recorded with the centrifuge and pressure plate methods at a given water potential is the run duration adopted. Because the centrifuge method is much less time consuming than the pressure plate method for determining the soil water retention curve, it is potentially an attractive alternative method. The aim of this study was to demonstrate the validity of the centrifugation method using a wide range of tropical soils.

\section{MATERIAL AND METHODS}

\section{The studied soils}

Two sets of Brazilian tropical soils were selected for the study: Set 1, 10 soil core samples located along a 10-km local hydrosequence across a Cerrado-Amazonia transition; and Set 2, 10 soil core samples located along a 350-km regional toposequence across the Cerrado (Reatto et al., 2007) (Table 1). The soil water retention properties for core samples were determined by using the pressure plate apparatus (Richards and 
Fireman, 1943) and the centrifugation method (Russel and Richards, 1938), following the laboratory procedures (Freitas Junior and Silva, 1984; Silva and Azevedo, 2002) applied for the whole centrifuged soil sample. The soils were described according to the field manual of Lemos and Santos (1996) and the Brazilian Soil Taxonomy (Embrapa, 1999). Core samples were collected by using stainless steel cylinders of $100 \mathrm{~cm}^{3}(5.1-\mathrm{cm}$ diam, 5.0-cm lengh) in the top, transitional and diagnostic horizons of the soils belonging to the local hydrosequence (Set 1) and in the sole diagnostic horizon of the soils belonging to the regional toposequence (Set 2). Disturbed soil samples were also collected in order to determine the particle density, particle size distribution, and organic $\mathrm{C}$ content according to the Brazilian standard procedures (Embrapa, 1997), which in general follow the international procedures (Klute, 1986; Page et al., 1982). Specifically, the particle size distribution was determined with the pipette method after dispersion in $1 \mathrm{~mol} \mathrm{~L}^{-1} \mathrm{NaOH}$. The particle density was measured by using $95 \%$ hydrated alcohol instead of distilled water, with $20 \mathrm{~g}$ of air-dried soil material in a 50-ml pycnometer; and the organic $\mathrm{C}$ content was determined by wet combustion with $0.27 \mathrm{~mol} \mathrm{~L}^{-1} \mathrm{~K}_{2} \mathrm{Cr}_{2} \mathrm{O}_{7}$ (Table 1).

\section{Soil-water retention properties}

The water retention properties were determined by using core soil samples (Silva et al., 2006). Gravimetric water contents $\left(w\right.$ in $\left.\mathrm{g} \mathrm{g}^{-1}\right)$ at $-1,-3,-6,-10,-33,-80,-400,-1000$, and $-1500 \mathrm{kPa}$ water potential were determined for the soils belonging to the local hydrosequence (Set 1), while it was determined only at $-1,-6,-10,-33,-300$, and -1500 $\mathrm{kPa}$ water potential for the soils belonging to the regional toposequence (Set 2). For every soil, samples were first saturated for $24 \mathrm{~h}$ and then weighed to determine the soil water content at saturation before submitting them to water extraction by applying the pressure plate and centrifuge methods. For the centrifuge method (Russel and Richards, 1938), we 
used a Kokusan $\mathrm{H}-1400 \mathrm{pF}$ centrifuge with an outer radii, $r_{e}$, of $8.3 \mathrm{~cm}$, specially designed to hold four soil samples (Fig. 1). In the centrifuge, each soil cylinder was inserted into a stainless sample holder provided by the centrifuge manufacturer. A drilled metallic plate and $205-\mu \mathrm{m}$ filter paper were placed at the bottom of the sample holder to facilitate retention of soil particles and drainage during centrifugation (Fig. 1). The Kokusan H$1400 \mathrm{pF}$ centrifuge was equipped with a mechanism to maintain and control the inside temperature within the range of 16 to $21^{\circ} \mathrm{C}$. This method is routinely used in the soil physics laboratory at Embrapa Cerrados (Silva and Azevedo, 2001).

For the centrifugation method, care was taken to keep the samples under constant rotation for 120 min to reach the soil water potential equilibrium corresponding to a given centrifugal force (Silva and Azevedo, 2002). After each centrifugation step, the samples were weighed and returned to the centrifuge to undergo a higher rotation speed. This procedure was repeated up to the last established water potential $(-1500 \mathrm{kPa})$. The samples were then oven-dried at $105^{\circ} \mathrm{C}$ for 24 hours to obtain the soil dry mass. Each applied rotation speed, whenever necessary, was adjusted by using an electronic tachometer. The equation used for calculating the average distribution of matric soilwater potential, $\bar{h}(\mathrm{kPa})$, along the soil sample of length, $\mathrm{L}(\mathrm{cm})$, subject to an angular velocity, $\omega\left(\operatorname{rad~s}^{-1}\right)$ was

$$
\bar{h}=\frac{k}{6} \omega^{2} g^{-1} L\left[L-3 r_{e}\right]
$$

where $g$ is the acceleration of gravity $\left(981 \mathrm{~cm} \mathrm{~s}^{-2}\right)$, and $k$ a constant value equal to $0.09807 \mathrm{kPa} \mathrm{cm}^{-1}$. For example, if $\omega=77.67 \mathrm{rad} \mathrm{s}^{-1}(741.6 \mathrm{rpm})$, then with $\mathrm{r}_{\mathrm{e}}=8.3 \mathrm{~cm}$ and $L=5.0 \mathrm{~cm}$, we obtain $\bar{h}=-10 \mathrm{kPa}$. Similarly, the angular velocity for $-1 \mathrm{kPa}$ is 24.56 $\operatorname{rad~s}^{-1}(234.5 \mathrm{rpm})$, and so on. Equation (1) takes into consideration the nonlinear behavior of the matric water potential distribution along the soil sample that is established 
during the centrifugation. Because of this nonlinearity, the average water potential is not necessarily at the midpoint of the soil sample, as pointed out by Khanzode et al. (2000).

In the case of the pressure plate apparatus (Richards and Fireman, 1943), the water potentials were established and controlled by an electrical automatic air-pressure pump. The time for equilibrium for the pressure plate varied depending on the magnitude of the applied pressure and the type of soil. Each pressure step was maintained until the water outflow nearly stopped, which took from 3 to $10 \mathrm{~d}$. In any case, the soil sample mass for both methods was measured at every water potential and the final water content determined at $-1500 \mathrm{kPa}$ after oven-drying the soil at $105^{\circ} \mathrm{C}$ for 24 hours. The water content at each potential was then calculated. The bulk density $\left(D_{\mathrm{b}}\right.$ in $\left.\mathrm{Mg} \mathrm{m}^{-3}\right)$ was determined on six replicates by using the oven-dry mass of the soil material contained in cylinders $100-\mathrm{cm}^{3}$ in volume. The volumetric water content $\left(\theta\right.$ in $\left.\mathrm{m}^{3} \mathrm{~m}^{-3}\right)$ was computed as

$$
\theta=\frac{1}{\rho} w D_{b}
$$

where, $\rho$, the water density $\left(\mathrm{Mg} \mathrm{m}^{-3}\right)$.

The soil water contents recorded with the two methods were fitted to the van Genuchten's model (van Genuchten, 1980) in order to allow a pairwise comparison between the resulting soil water retention curves and thus additionally validating the similarity between the methods. This model was expressed by

$$
\theta=\theta_{r}+\left(\theta_{s}-\theta_{r}\right)\left[1+(\delta|h|)^{n}\right]^{(-1+1 / n)}
$$

where $\theta$, the volumetric soil water content $\left(\mathrm{m}^{3} \mathrm{~m}^{-3}\right), \theta_{r}$, the fitted residual volumetric soil water content $\left(\mathrm{m}^{3} \mathrm{~m}^{-3}\right), \theta_{s}$, the measured saturated volumetric soil water content $\left(\mathrm{m}^{3} \mathrm{~m}^{-3}\right)$, $h$, the matric soil water potential $(\mathrm{kPa})$, and $\delta$ and $n$ are fitting parameters $\left(\mathrm{kPa}^{-1}\right.$ and 
dimensionless, respectively). The fitted parameters $\left(\theta_{r}, \delta\right.$ and $\left.n\right)$ were obtained with the solver routine embedded in the Microsoft Excel program.

\section{Statistical Analysis of the data sets}

Water contents recorded at every water potential for the soils belonging to Set 1 were compared in a point-wise manner by plotting each measured soil water content obtained with the pressure plate and centrifuge methods using appropriate statistical analysis as proposed by Graybill (1976) (see Appendix).

The water retention properties of the soils belonging to Set 2 were used to establish the similarity of the overall soil water retention curves as determined with the pressure plate and centrifuge methods and adjusted by the van Genuchten model. The statistical analysis of this comparison follows the $F$ test used by Silva and Azevedo (2002), which somewhat resembles the curve comparison method proposed by Motolusky and Christopoulos (2003) to select nonlinear models fitted to a given set of data points.

\section{RESULTS AND DISCUSSION}

\section{Analysis of the elementary measured water contents}

On the basis of the data recorded with the soils belonging to the hydrosequence (Set 1), we gathered a total of 468 average soil water contents obtained with either the pressure plate $\left(\theta_{p}\right)$ or centrifuge $\left(\theta_{c}\right)$ method. These water contents were compared in a pointwise manner (Fig. 2), to determine if the outcome follows, in general, a 1:1 relationship. The fitted straight line showed a high correlation $\left(R^{2}=0.9891\right)$. The slope was very close to $1(0.9796)$ and the intercept to 0 (0.01136) (Fig. 2). The statistical analysis applied to determine the significance of the deviation between the 1:1 model and 
the fitted straight line using the Graybill test showed that both models were statistically identical for a $P=0.0109$ (Fig. 2). As a result, the comparison of pointwise soil water content measured with the pressure plate $\left(\theta_{p}\right)$ and centrifuge $\left(\theta_{c}\right)$ method for soils of the hydrosequence (Cerrado-Amazonia transition) showed that, for the two methods, the water contents corresponding to the range from -1 to $-1500 \mathrm{kPa}$ are statistically identical for a large range of soil types (Plinthaquox, Fluvaquent, Hapludox) (Table 1). Considering the good agreement found between these methods, it could be inferred that the overestimated water contents recorded by Balbino et al. (2002) and Khanzode et al. (2000, 2002) with the centrifuge technique would be due to some inappropriate combined consideration of the centrifugation run duration, geometry of the soil sample, and type of soil structure and not necessarily to inappropriate equilibrium conditions as suggested by Khanzode et al. (2000, 2002). Thus, the use of artificially packed soil samples such as in the study of Khanzode et al. $(2000,2002)$ might have affected the water retention process, especially at low soil water potentials. On the other hand, Balbino et al. (2002) plotted in the same graph water contents measured at a given matric potential with the centrifuge and pressure plate methods according to the clay content. In doing so, a unique relationship was assumed between the water content at a given water potential and the clay content, which is highly questionable because of the contribution of the mineralogy and assemblage of the fine fractions to the water retention properties (Bruand and Tessier, 2000).

\section{Analysis of the water retention curves}

For every horizon of the regional toposequence studied (Set 2), the van Genuchten model was fitted to the water contents recorded with the centrifuge method and then to those recorded with the pressure plate method (Fig. 3). The statistical results based on the 
$F$ test for curve comparison (Silva and Azevedo, 2002) showed that the smallest probability of rejecting the null hypothesis of similarity for the water retention curves measured with the two methods was $P=0.0106$ for the soil sample from $\mathrm{O} 9$, while the highest similarity was observed for the soil sample from $\mathrm{O} 3(P=0.7388)$. The variation of sample height was $<2 \%$ for all the samples studied up to $-80 \mathrm{kPa}$, then reaching 20 to $30 \%$ according to the sample at $-1500 \mathrm{kPa}$. Despite this height variation, which resulted from sample deformation due to centrifugal force and possibly some sample shrinkage because of water removal, the soil water retention curves obtained with the two methods did not differ significantly (Fig. 3). Finally, detailed analysis of the curves showed that the difference in water content between the two methods was the largest at $-1 \mathrm{kPa}$ on replicate samples (except for O10) (Fig. 3). This difference would be related to the large change in water content with respect to potential at high potential, thus generating errors whatever the method used.

\section{CONCLUSIONS}

Our results showed good agreement between the centrifuge and pressure plate methods when applied to the large range of tropical soils studied in a routine laboratory application. Comparison of the water content recorded in a point-wise manner and of the water retention curve showed clearly that there was no difference when the appropriate methodology was used for the centrifuge method. These results showed also that the centrifuge should be considered an appropriate method because it requires a relatively short time, compared with the pressure plate method, for the determination of the whole water retention curve. Indeed, a soil water retention curve with nine pressure points requires from 2 to 3 mo to be determined in a 24-h running time using the pressure plate 
method, while the centrifuge method requires only $120 \mathrm{~min}$ of rotation time for every pressure point, for a total time of only $4 \mathrm{~d}$ including the time required to oven dry the soil.

\section{APPENDIX}

Graybill (1976) proposed a mathematical expression to calculate an $\mathrm{F}_{\mathrm{w}}$-statistic distribution value to test the significance of a null hypothesis of similarity of a set of linear models. In this study, the test was applied to Set 1 and consisted in verifying the similarity between the 1:1 model and the straight line fitted to the experimental data. The hypothesis of equality is rejected if and only if $F_{w} \geq F_{\alpha: 2, N-4}$ is met. In this inequality, $F_{\alpha: 2, N-4}$ is the $F$ distribution value corresponding to a previously established Type I error $\alpha$ with 2 and $N-4$ degrees of freedom; $N$ is the total number of data points of both models. The statistic $F_{w}$ (Graybill, 1976) can be expressed as follows for soils from Set 1:

$$
F_{w}=\left\{\frac{\sum_{m=1}^{2} \sum_{i=1}^{N_{m}}\left(\theta_{C_{m i}}-\bar{\theta}_{C_{m}}\right)^{2}-\frac{\left[\sum_{m=1}^{2} \sum_{i=1}^{N_{m}}\left(\theta_{C_{m i}}-\bar{\theta}_{C_{m}}\right)\left(\theta_{P_{m i}}-\bar{\theta}_{P m}\right)\right]^{2}}{\sum_{m=1}^{2} \sum_{i=1}^{N_{m}}\left(\theta_{P_{m i}}-\bar{\theta}_{P_{m}}\right)^{2}}-\sum_{m=1}^{2} \sum_{i=1}^{N_{m}}\left(\theta_{C_{m i}}-\hat{\theta}_{C_{m i}}\right)^{2}}{\sum_{m=1}^{2} \sum_{i=1}^{N_{m}}\left(\theta_{C_{m i}}-\hat{\theta}_{C_{m i}}\right)^{2}}\right\}\left(\frac{N-4}{2}\right)
$$

where $m=1$ (model 1:1) and $m=2$ (centrifuge versus pressure plate); $I$ is an index for a given water content value; $\theta_{C_{m i}}$ is a measured centrifuge water content for a given $\mathrm{m}$ and $i ; \theta_{P_{m i}}$ is the measured pressure plate-water content for a given $m$ and $i ; \bar{\theta}_{C_{m}}$ is the average centrifuge water content for a given $m ; \bar{\theta}_{P_{m}}$ is the average pressure plate water content for a given $\mathrm{m} ; \hat{\theta}_{C_{m i}}$ is a calculated centrifuge-water content for a given $m$ and $i$; 
$\hat{\theta}_{P_{m i}}$ is a calculated pressure plate-water for a given $m$ and $i ; N_{m}$ is the number of data points for each model. For $m=1$, it was set $\theta_{C_{m i}}=\theta_{P_{m i}} ; \bar{\theta}_{C_{m}}=\bar{\theta}_{P_{m}} ; \hat{\theta}_{C_{m i}}=\hat{\theta}_{P_{m i}}$.

The statistic $F_{c}$ was computed as follows in this study for soils from data Set 2:

$$
F_{c}=\frac{\left|R S S_{\text {comb }}-\left(R S S_{\text {met } 1}+R S S_{\text {met } 2}\right)\right|}{\left(R S S_{\text {met } 1}+R S S_{\text {met } 2}\right)}\left(\frac{D F_{\text {den }}}{D F_{\text {num }}}\right)
$$

where $R S S_{\text {metl }}$ and $R S S_{\text {met2 }}$ are the residual sum of squares, resulting from fitting a given soil water retention model to the data obtained from either pressure plate (metl) or centrifuge methods (met2), respectively; $R S S_{\text {comb }}$ represents the residual sum of squares, obtained from fitting the same soil water retention model to the data altogether obtained from both pressure plate and centrifuge; $D F_{\text {num }}$ and $D F_{\text {den }}$ represent the degrees of freedom of numerator and denominator, respectively, corresponding to difference between the number of data points and the parameters from each fitting.

\section{ACKNOWLEDGEMENTS}

We thank the Empresa Brasileira de Pesquisa Agropecuária (EMBRAPA) for its financial support of A. Reatto's work in France. We also thank Wantuir Caixeta Vieira, technician assistant in the Embrapa Cerrados physical laboratory, for its contribution to the study. This research is part of the project Embrapa Cerrados, $\mathrm{n}^{\circ}$ 02.02.5.05.5.00 "Development of pedotransfer functions for estimating soil water retention and saturated hydraulic conductivity from Latosols of the Biome Cerrado". 


\section{REFERENCES}

Arulanandan, K., P. Y. Thompson, B. L. Kutter, N. J. Meegoda, K. K. Muraleetharan, and C. Yogachandran. 1988. Centrifuge modeling of transport processes for pollutants in soils. J. Geotech. Eng - Ascel. 114 (2): 185-205.

Balbino, L. C., M. Brossard, J-C. Leprun, and A. Bruand. 2002. Mise en valeur des Ferralsols de la région du Cerrado (Brésil) et évolution de leurs propriétés physiques: une étude bibliographique. Étude et Gestion des Sols. 9 (2): 83-104.

Briggs, L. J., and J. W. McLane. 1910. Moisture equivalent determinations and their application. Proc. Am. Soc. Agron. 2: 138-147.

Bruand, A., and D. Tessier. 2000. Water retention properties of the clay in soils developed on clayed sediments: significance of parent material and soil history. Eur. J. Soil Sci. 51: 679-688.

Caputo, M. C., and J. R. Nimmo. 2005. Quasi-steady centrifuge method for unsaturated hydraulic properties. Water Resour. Res. 41 (11): W11504.

Centurion J. F., M. H. Moraes, and C. L. F. Della Libera. 1997. Comparação de métodos para determinação da curva de retenção de água em solos. Rev. Bras. Cienc. Solo. 21: $173-179$.

Embrapa. 1997. Manual de métodos de análise de solo. Empresa Brasileira de Pesquisa Agropecuária, Rio de Janeiro, RJ.

Embrapa. 1999. Sistema Brasileiro de Classificação de Solos. Empresa Brasileira de Pesquisa Agropecuária, Rio de Janeiro, RJ.

Freitas Júnior, E., and E.M., Silva. 1984. Uso da centrífuga para determinação da curva de retenção de água do solo, em uma única operação. Pesq. Agropec. Bras. 19: 14231428. 
Graybill, F. A. 1976. Theory and application of the linear model. Duxbury press, Colorado State University.

IUSS Working Group WRB. 2006. World reference base for soil resources 2006. World Soil Resources Reports º 103. FAO, Rome.

Lemos, R. C., and R. D. Santos. 1996. Manual de descrição e coleta de solo no campo. Sociedade Brasileira de Ciência do Solo, Campinas, SP.

Medeiros, S. D. 1987. Determinação da curva de retenção da água no solo através do fatiamento de amostras centrifugadas. Ph.D. thesis, ESALQ-USP, Piracicaba, SP.

Motolusky H. J., and A. Christopoulos. 2003. Fitting models to biological data using linear and nonlinear regression. A practical guide to curve fitting. GraphPad Software Inc., San Diego CA, www.graphpad.com.

Nakajima, H., and A. T. Stadler. 2006. Centrifuge modeling of one-step outflow testes for unsaturated parameter estimations. Hydrol. Earth Syst. Sci. 10: 715-729.

Nimmo, J. R., K. S. Perkins, and A. M. Lewis. 2002. Steady-state centrifuge. p. 903-916. In J. H. Dane and G. C. Topp (eds.). Methods of Soil Analysis, Part 4, Physical Methods. Soil Sci. Soc. Amer., Madison, Wisconsin, USA.

Odén, S. 1975. An integral method for the determination of moisture retention curves by centrifugation. Grundförbättring. 27 (4): 137-143.

Khanzode, R. M., D. G. Fredlund, and S. K. Vanapalli. 2000. A new test procedure to measure the soil-water characteristic curves using a small-scale centrifuge. p.335-340. In Proc. Asian Conference on Unsaturated Soils from Theory to Practice. UNSATASIA. 
Khanzode, R. M., S. K. Vanapalli, and D. G. Fredlund. 2002. Measurement of soil-water characteristics curves for fine-grained soils using a small-scale centrifuge. Can. Geotech. J. 39: 1209-1217.

Klute, A. 1986. Methods of Soil Analysis, Part 1, Physical and Mineralogical Methods. Amer. Soc. Agronomy and Soil Sci. Soc. Amer., Madison, Wisconsin, USA.

Page, A. L., R. H. Miller, and D. R. Keeney. 1982. Methods of Soil Analysis, Part 2, Chemical and Microbiological Properties. Amer. Soc. Agronomy and Soil Sci. Soc. Amer., Madison, Wisconsin, USA.

Reatto, A., A. Bruand., E. M. Silva, E. S. Martins, and M. Brossard. 2007. Hydraulic properties of the diagnostic horizon of Latosols of a regional topossequence across the Brazilian Central Plateau. Geoderma. 139: 51-59.

Richards, L. A., and M. Fireman. 1943. Pressure-plate apparatus for measuring moisture sorption and transmission by soils. Soil Sci. 56: 395-404.

Russel, M. B., and L. A. Richards. 1938. The determination of soil moisture energy relations by centrifugation. Soil Sci. Soc. Proc. 3: 65-69.

Silva, E.M., and J.A. Azevedo. 2001. Período de centrifugação adequado para levantamento da curva de retenção da água em solos do Bioma Cerrado. B.P. Embrapa Cerrados. 8: 1-40.

Silva, E.M., and J.A. Azevedo. 2002. Influência do período de centrifugação na curva de retenção de água em solos de Cerrado. Pesq. Agropec. Bras. 37: 1487-1494.

Silva, E. M., J. E. F. W. Lima, J. A. Azevedo, and L. N Rodrigues. 2006. Valores de tensão na determinação da curva de retenção de água de solos do Cerrado. Pesq. Agropec. Bras. 41 (2): 323-330. 
Simunek, J., and J. R. Nimmo. 2005. Estimating soil hydraulic parameters from transient flow experiments in a centrifuge using parameter optimization technique. Water Resour. Res. 41 (4): W04015.

Singh, D. N., and S. J. Kuriyan. 2002. Estimation of hydraulic conductivity of unsaturated soils using a geotechnical centrifuge. Can. Geotech. J. 39: 684-694.

Soil Survey Staff. 2006. Keys to Soil Taxonomy. 10th ed. USDA-Natural Resources Conservation Service. Washington, DC.

Taylor, R. N. 1995. Geotechnical Centrifuge Technology. Blackie Academic and Professional, London.

Thomas, M. D., and K. Harris. 1925. The moisture equivalent of soils. Soil Sci. 21 (6): 411-423.

van Genuchten, M. T. 1980. A closed form equation for predicting the hydraulic conductivity of unsaturated soils. Soil Sci. Soc. Am. J. 44: 892-898. 


\section{List of Tables}

3

4 Table 1. General characteristics of the two sets of soil samples from Brazilian Tropical 5 soils studied.

6 


\section{$7 \quad$ List of Figures}

8 Fig. 1. Saturated soil core samples (a), empty sample holders, with and without filter

9 paper (b), and sample holders positioned inside the centrifuge rotor chamber (c).

10

11 Fig. 2. Point-wise comparison of measured volumetric soil-water content values from

12 both pressure plate and centrifuge methods for soils from Embrapa Cerrados database set

13 (1). $\mathrm{F}_{\mathrm{w}}$ : F-test statistic value, according to (Graybill, 1976). $p$ : probability of $F_{w}$ according

14 to F-distribution for 2 and 464 degrees of freedom.

15

16 Fig. 3. Soil-water retention fitting using van Genuchten model using results from both

17 pressure plate and centrifuge methods for soils from data set (2). $O$ : Oxisols, $F_{c}$ : F-test

18 statistic value, $p$ : probability of $F_{c}$ according to F-distribution for 3 and 39 degrees of 19 freedom.

20 
Table 1. General characteristics of the two sets of soil samples from Brazilian Tropical soils studied

\begin{tabular}{|c|c|c|c|c|c|c|c|c|c|c|c|c|c|}
\hline \multirow[b]{2}{*}{ Set } & \multicolumn{3}{|c|}{ Geographical Coordinates } & \multirow[b]{2}{*}{ Soil Type } & \multirow[b]{2}{*}{ Horiz. } & \multirow[b]{2}{*}{$\begin{array}{l}\text { Depth } \\
(\mathrm{cm})\end{array}$} & \multirow{2}{*}{$\begin{array}{l}\text { Munsell } \\
\text { Color } \\
\text { (wet) }\end{array}$} & \multicolumn{3}{|c|}{ Particle size distribution $(\mu \mathrm{m})$} & \multicolumn{2}{|c|}{ Density } & \multirow{2}{*}{$\begin{array}{c}\text { O.C. } \\
\left(\mathrm{g} \mathrm{kg}^{-1}\right)\end{array}$} \\
\hline & Id. & $\begin{array}{l}\text { Latitud } \\
\text { (decimal }\end{array}$ & $\begin{array}{l}\text { Longitud } \\
\text { degrees) }\end{array}$ & & & & & $50-2000$ & $\begin{array}{c}2-50 \\
-\left(\mathrm{g} \mathrm{kg}^{-1}\right)\end{array}$ & $<2$ & $D_{\mathrm{p}}$ & $\begin{array}{r}D_{\mathrm{b}} \\
\left.\mathrm{m}^{-3}\right)-\end{array}$ & \\
\hline & S1 & -10.03502778 & -49.84908333 & Typic Plinthaquox $^{(1)}$ - Plintossolo Pétrico ${ }^{(2)}$ - Plinthic Phintosol ${ }^{(3)}$ & A & $0-5$ & $7.5 \mathrm{YR} 3 / 1$ & 590 & 80 & 330 & 2.45 & 0.97 & 2.77 \\
\hline & & & & & $\mathrm{AB}_{\mathrm{f}}$ & $5-20$ & $10 \mathrm{YR} 4 / 1$ & 600 & 50 & 350 & 2.45 & 1.27 & 1.56 \\
\hline \multirow{6}{*}{ 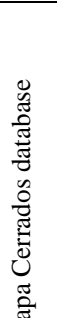 } & S2 & -10.05530556 & -49.86936111 & Typic Plinthaquox $^{(1)}$ - Plintossolo Pétrico ${ }^{(2)}$ - Plinthic Phintosol ${ }^{(3)}$ & A & $0-5$ & $7.5 \mathrm{YR} 4 / 2$ & 791 & 30 & 179 & 2.55 & 1.32 & 3.24 \\
\hline & S4 & -10.0094444 & -49.88155556 & Typic Fluvaquent $^{(1)}$ - Gleissolo Háplico ${ }^{(2)}$ - Plinthic Gleysol ${ }^{(3)}$ & A & $0-12$ & $10 \mathrm{YR} 3 / 1$ & 174 & 25 & 801 & 2.58 & 1.25 & 1.75 \\
\hline & & & & & $\mathrm{AC}$ & $12-42$ & $10 \mathrm{YR} 4 / 2$ & 166 & 28 & 806 & 2.64 & 1.26 & 0.83 \\
\hline & & & & & $\mathrm{C}_{\mathrm{gf}}$ & $42-65$ & $10 \mathrm{YR} 7 / 3$ & 192 & 11 & 797 & 2.76 & 1.24 & 0.34 \\
\hline & S5 & -10.06375000 & -49.90833333 & Typic Fluvaquent $^{(1)}$ - Gleissolo Háplico ${ }^{(2)}$ - Dystric Gleysol ${ }^{(3)}$ & $\mathrm{A}$ & $0-22$ & $10 \mathrm{YR} 3 / 1$ & 568 & 83 & 349 & 2.45 & 1.10 & 2.52 \\
\hline & & & & & $\mathrm{AC}$ & $22-35$ & $10 \mathrm{YR} 5 / 1$ & 582 & 70 & 348 & 2.51 & 1.12 & 1.60 \\
\hline \multirow[t]{4}{*}{$\vec{\Xi}$} & S6 & -10.06366667 & -49.90841667 & Xanthic Hapludox $^{(1)}$ - Latossolo Amarelo ${ }^{(2)}$-Xanthic Ferralsol ${ }^{(3)}$ & $A_{1}$ & $0-25$ & $7.5 \mathrm{YR} 4 / 2$ & 542 & 60 & 398 & 2.42 & 1.02 & 1.92 \\
\hline & & & & & $\mathrm{A}_{2}$ & $25-65$ & $10 \mathrm{YR} 5 / 2$ & 526 & 183 & 291 & 2.55 & 1.09 & 1.67 \\
\hline & & & & & $\mathrm{B}_{\mathrm{w} 1}$ & $65-100$ & $10 \mathrm{YR} 6 / 3$ & 542 & 40 & 418 & 2.58 & 1.04 & 0.89 \\
\hline & & & & & $B_{w 2}$ & $100-120$ & $10 \mathrm{YR} 6 / 2$ & 577 & 32 & 391 & 2.72 & 1.08 & 0.54 \\
\hline \multirow[b]{3}{*}{0} & S7 & -10.03627778 & -49.84877778 & Typic Fluvaquent ${ }^{(1)}$ - Gleissolo Háplico ${ }^{(2)}$ - Plinthic Gleysol ${ }^{(3)}$ & A & $0-20$ & $10 \mathrm{YR} 3 / 1$ & 770 & 49 & 181 & 2.58 & 1.11 & 2.03 \\
\hline & & & & & $\mathrm{AC}$ & $20 / 35-50$ & $10 \mathrm{YR} 5 / 2$ & 795 & 19 & 186 & 2.58 & 1.11 & 1.43 \\
\hline & & & & & $\mathrm{C}_{\mathrm{gf}}$ & $50-80$ & $10 \mathrm{YR} 6 / 2$ & 720 & 37 & 243 & 2.65 & 1.08 & 0.59 \\
\hline \multirow{3}{*}{ 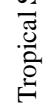 } & S8 & -10.07333333 & -49.87177778 & Typic Fluvaquent $^{(1)}$ - Gleissolo Háplico ${ }^{(2)}$ - Plinthic Gleysol ${ }^{(3)}$ & $\mathrm{A}$ & $0-25$ & $7.5 \mathrm{YR} 4 / 1$ & 783 & 46 & 171 & 2.61 & 1.33 & 1.38 \\
\hline & & & & & $\mathrm{AC}$ & $25-35 / 40$ & $7.5 \mathrm{YR} 5 / 2$ & 74 & 43 & 209 & 2.61 & 1.28 & 0.86 \\
\hline & & & & & $\mathrm{C}_{\mathrm{gf}}$ & $35 / 40-70$ & $10 \mathrm{YR} 7 / 2$ & 601 & 64 & 335 & 2.72 & 1.16 & 0.36 \\
\hline \multirow{2}{*}{$\begin{array}{l}\ddot{\Delta} \\
\ddot{D} \\
\vec{n}\end{array}$} & S9 & -10.07444444 & -49.87219444 & Xanthic Hapludox $^{(1)}$ - Latossolo Amarelo ${ }^{(2)}$ - Xanthic Ferralsol ${ }^{(3)}$ & $\mathrm{A}$ & $0-15 / 20$ & 10YR3/1 & 464 & 168 & 368 & 2.45 & 0.85 & 3.80 \\
\hline & S10 & -10.07444444 & -49.87219444 & Xanthic Hapludox ${ }^{(1)}$ - Latossolo Amarelo ${ }^{(2)}-$ Xanthic Ferralsol $^{(3)}$ & $\mathrm{A}$ & $0-30 / 40$ & $5 Y R 2.5 / 1$ & 403 & 14 & 456 & 2.33 & 0.66 & 4.52 \\
\hline \multirow{12}{*}{ 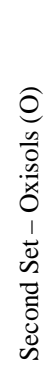 } & & & & & $\mathrm{AB} / \mathrm{BA}$ & $30 / 40-70$ & $7.5 Y R 2.5 / 1$ & 398 & 111 & 49 & 2.33 & 0.71 & 3.17 \\
\hline & & & & & $B_{B}$ & & 7.5YR4/1 & 493 & 40 & 46 & 2.58 & 0.94 & 1.08 \\
\hline & O1 & -16.6346500 & -49.4428100 & Rhodic Acrustox $^{(1)}$ - Latossolo Vermelho ${ }^{(2)}$ - Rhodic Ferralsol ${ }^{(3)}$ & $\mathrm{Bw}_{2}$ & $100-160$ & $2.5 \mathrm{YR} 3 / 6$ & 440 & 40 & 520 & 2.73 & 1.21 & 0.34 \\
\hline & $\mathrm{O} 2$ & -15.6186510 & -47.7597840 & Typic Acrustox ${ }^{(1)}$ - Latossolo Vermelho ${ }^{(2)}$ - Orthic Ferralsol ${ }^{(3)}$ & $\mathrm{Bw}_{2}$ & $115-200$ & 2.5 YR $4 / 8$ & 250 & 140 & 610 & 2.76 & 0.90 & 0.61 \\
\hline & $\mathrm{O} 3$ & -15.6150640 & -47.7515510 & Xanthic Acrustox $^{(1)}$ - Latossolo Amarelo ${ }^{(2)}$ - Xanthic Ferralsol ${ }^{(3)}$ & $\mathrm{Bw}_{2}$ & $130-180$ & 10YR6/6 & 160 & 90 & 750 & 2.72 & 0.88 & 0.02 \\
\hline & $\mathrm{O} 4$ & -15.6093700 & -47.7378500 & Plinthic Acrustox ${ }^{(1)}$ - Latossolo Amarelo plíntico ${ }^{(2)}$ - Plinthic Ferralsol ${ }^{(3)}$ & 3) $\mathrm{Bw}_{1}$ & $60-110$ & 10YR5/8 & 690 & 10 & 300 & 2.64 & 1.18 & 0.34 \\
\hline & O5 & -15.6083670 & -47.7135500 & Typic Acrustox ${ }^{(1)}$ - Latossolo Vermelho ${ }^{(2)}$ - Orthic Ferralsol ${ }^{(3)}$ & $\mathrm{Bw}_{1}$ & $57-120$ & $2.5 \mathrm{YR} 3 / 6$ & 300 & 150 & 550 & 2.76 & 1.02 & 0.62 \\
\hline & O6 & -15.5246390 & -47.6986690 & Rhodic Acrustox $^{(1)}$ - Latossolo Vermelho ${ }^{(2)}$ - Rhodic Ferralsol ${ }^{(3)}$ & $\mathrm{Bw}_{2}$ & $140-200$ & $10 \mathrm{R} 3 / 6$ & 130 & 90 & 780 & 2.65 & 0.83 & 0.02 \\
\hline & O7 & -15.2207000 & -47.7024500 & Typic Acrustox $^{(1)}$ - Latossolo Vermelho Amarelo ${ }^{(2)}$ - Orthic Ferralsol ${ }^{(3)}$ & ) $\mathrm{Bw}_{2}$ & $96-200$ & $5 \mathrm{YR} 5 / 9$ & 160 & 140 & 700 & 2.76 & 0.96 & 0.59 \\
\hline & O8 & -15.2213020 & -47.7020760 & Rhodic Acrustox ${ }^{(1)}$ - Latossolo Vermelho ${ }^{(2)}$ - Rhodic Ferralsol ${ }^{(3)}$ & $\mathrm{Bw}_{2}$ & $95-200$ & $2.5 \mathrm{YR} 3 / 6$ & 170 & 70 & 760 & 2.88 & 0.98 & 0.61 \\
\hline & O9 & -15.1862160 & -47.7177710 & Rhodic Acrustox $^{(1)}$ - Latossolo Vermelho ${ }^{(2)}$ - Rhodic Ferralsol ${ }^{(3)}$ & $\mathrm{Bw}_{2}$ & $100-180$ & $2.5 \mathrm{YR} 3 / 6$ & 170 & 80 & 750 & 2.80 & 1.06 & 0.01 \\
\hline & 010 & -15.0683610 & -47.7741110 & Rhodic Acrustox $^{(1)}$ - Latossolo Vermelho ${ }^{(2)}$ - Rhodic Ferralsol ${ }^{(3)}$ & $\mathrm{Bw}_{2}$ & $100-140$ & $10 \mathrm{R} 4 / 8$ & 180 & 70 & 750 & 2.76 & 0.88 & 0.02 \\
\hline
\end{tabular}

ten soils (S) from Brazilian Cerrado-Amazonia transition, $\mathrm{Secon}$ 1999), (3) Wold Refer 

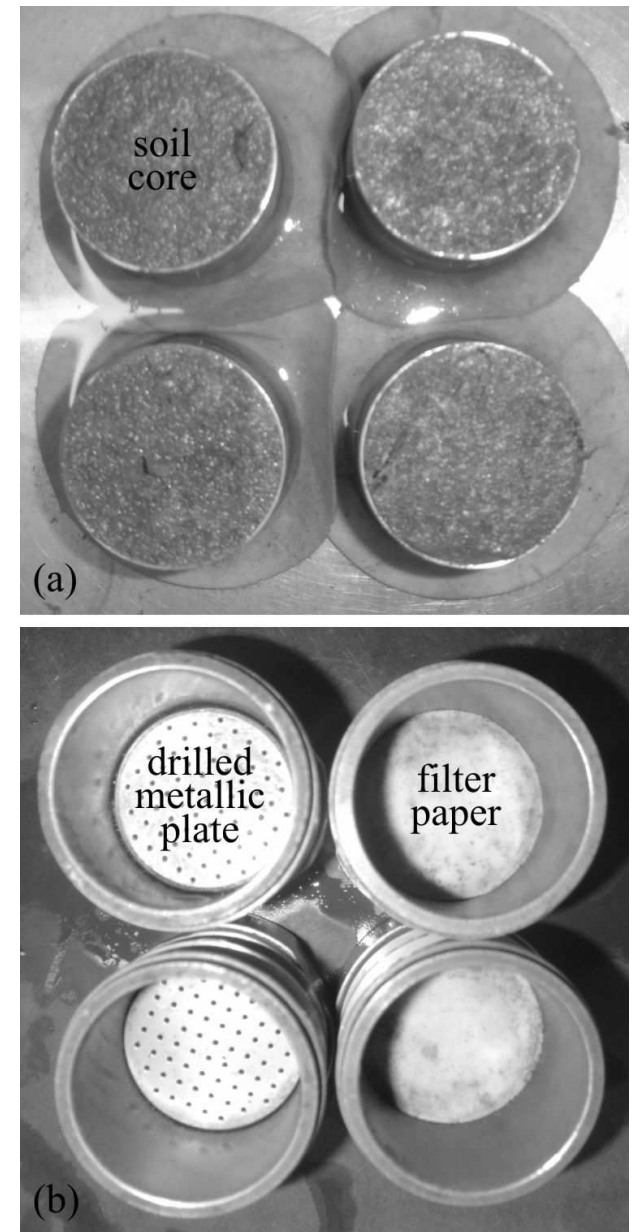

30 Fig. 1. Saturated soil core samples (a), empty sample holders with and without filter

31 paper (b) and sample holders positioned inside the centrifuge rotor chamber (c). 


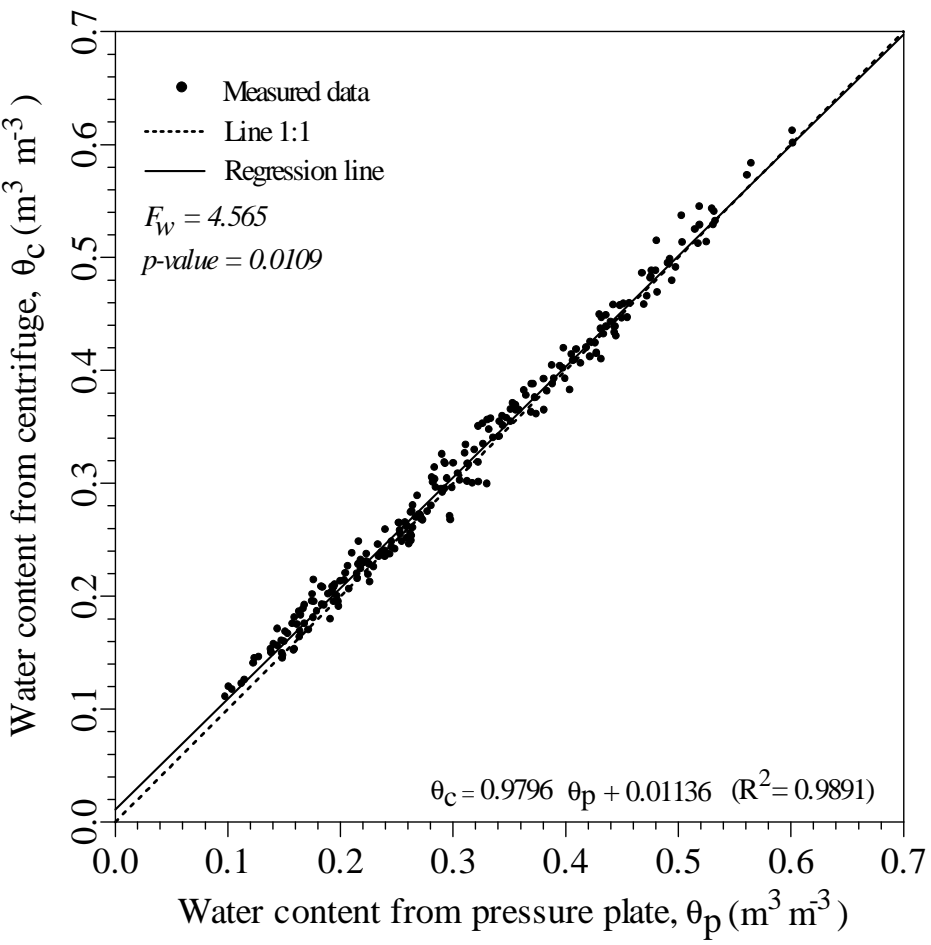

36

37 Fig. 2. Point-wise comparison of measured volumetric soil-water content values from

38 both pressure plate and centrifuge methods for soils from Embrapa Cerrados database

39 set (1). $\mathrm{F}_{\mathrm{w}}$ : F-test statistic value, according to (Graybill, 1976). p: probability of $F_{w}$

40 according to F-distribution for 2 and 464 degrees of freedom.

41

42 

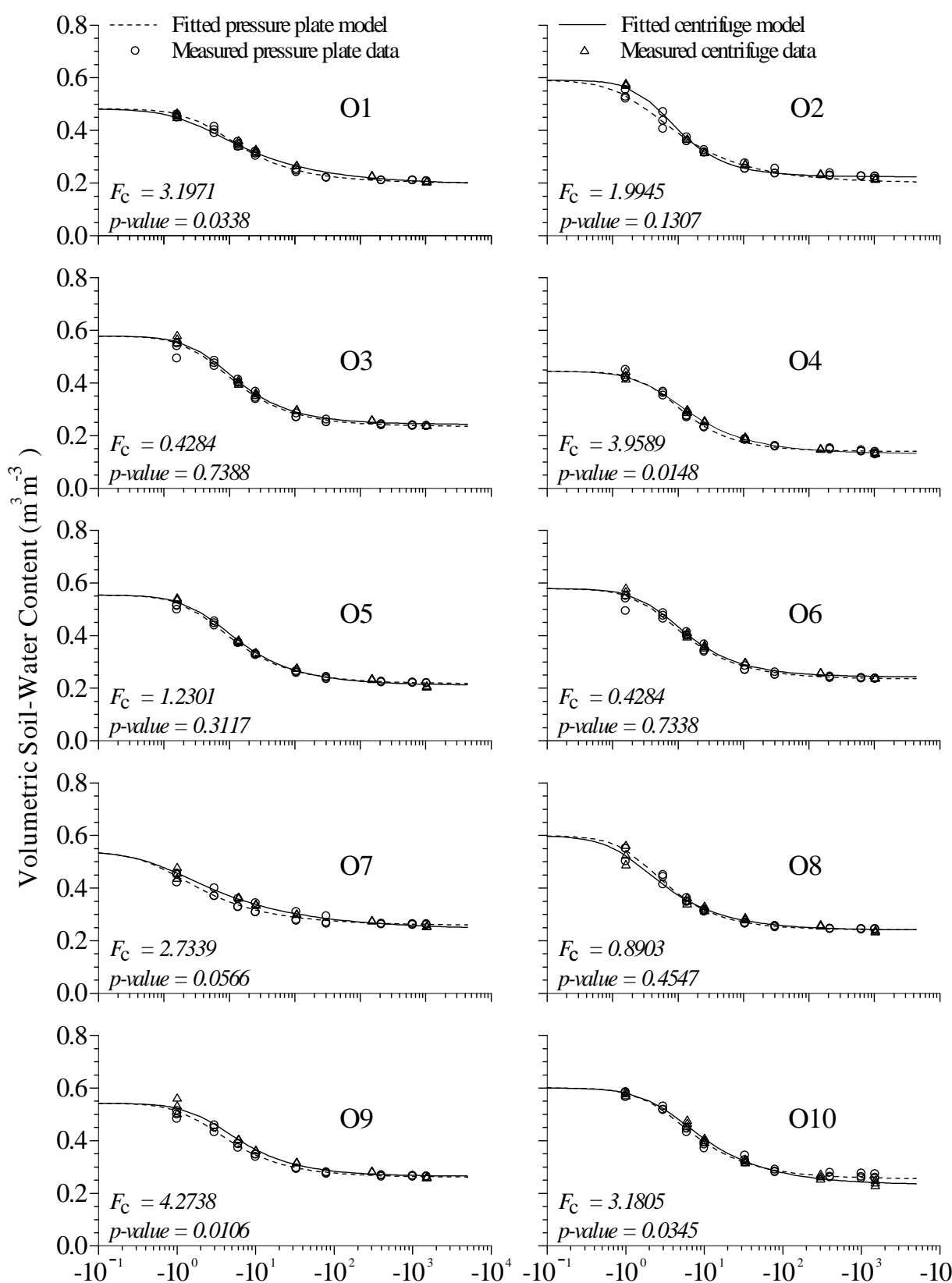

45 Fig. 3. Soil-water retention fitting using van Genuchten model using results from both

46 pressure plate and centrifuge methods for soils from data set (2). O: Oxisols, $\mathrm{F}_{\mathrm{c}}$ : F-test

47 statistic value, $p$ : probability of $F_{c}$ according to F-distribution for 3 and 39 degrees of 48 freedom. 